\title{
A Study on Corporate Governance of Mixed Ownership Enterprises
}

\author{
Lei Ruan* \\ School of Business \\ Northeast Normal University \\ Changchun, China \\ ruan1779@foxmail.com
}

\author{
Ming Yin \\ School of Business \\ Northeast Normal University \\ Changchun, China
}

\begin{abstract}
As a form of enterprise organization with Chinese characteristic, mixed ownership is not only different from the classical private ownership enterprise in western countries, but different from the public ownership enterprise which is generally accepted by socialist countries. The mixed-ownership enterprise as a unique form of enterprise organization has been widely existed in the current practice of enterprise management in China, and has been popularized and supported. Considering of this, it is necessary to study the particularity of ownership structure of mixed-ownership enterprises, and the differences of the corporate governance mechanism which are led by it. This paper explores the integration of corporate governance of mixedownership enterprises with Chinese market economy and the improvement of countermeasures. By doing so, it hopes to provide some references for the study of socialist market economy with Chinese characteristics.
\end{abstract}

Keywords-State-owned enterprises; Mixed ownership reform; Corporate governance; Equity structure

\section{INTRODUCTION}

As a unique form of corporate organization, mixed ownership has been existed for a long time in the development of China's market economy, but it has not yet received much attention and promotion in the mainstream capitalist countries in the West. In addition to PPP and special circumstances (economic crisis outbreak), mixed ownership has been used as a transitional means [1-2]. In China, the emergence of mixed ownership enterprises is mainly due to the reform of stateowned enterprises and economic transformation, and it has been developed from the path of the exploration of the combination of state-owned enterprises and market economy. The mixed ownership enterprises with the joint ownership of state-owned and non-state-owned shareholders can not only solve the problems of imperfect enterprises system in stateowned enterprises, such as the administration of corporate governance and the false establishment of the board of directors, but also can solve the disadvantages in private enterprises, such as the investment of these enterprises is too narrow as well as their imperfect management system[3]. Nowadays, mixed ownership reform has been piloted in various parts of China, the development of mixed ownership enterprises has attracted attention from all parties.

In the process of state-owned economic strategy adjustment and the reform of state-owned enterprises in China, a large

This work supported by the Fundamental Research Funds for the Central Universities (Grant No. 2412018QD028), Jilin Scientific and Technological Development Program (Grant No. 20180418095FG), Social Science research project of Jilin Province Education Department (Grant No. JJKH20180057SK). number of mixed ownership enterprises have been set up through many forms, such as the absorption of foreign capital and private capital, and the encouragement of non-state-owned capital to participate in shares in new government investment projects. According to the registration data from central enterprise property, it is showed that by the end of 2012, there have been a total of 378 listed companies controlled by central enterprises and their subsidiaries, and the proportion of nonstate-owned stares in listed companies had exceeded $53 \%$. Among the 681 listed companies controlled by local stateowned enterprises, the proportion of non-state-owned shares in listed companies had exceeded $60 \%$, forming a mixed ownership structure with Chinese characteristics. The proportion of enterprises with mixed ownership has increased from $65.7 \%$ to $68.9 \%$ in central enterprises and subsidiaries at all levels during the year from 2013 to 2016. According to the preliminary statistics, the number of newly-added mixed ownership enterprises of central enterprises increased by over 700 in 2017, of which more than 338.6 billion RMB of social capital have been introduced through the capital market. On the whole, central enterprises have achieved a wide range of blending with social capital from the perspective of property rights. The emergence of a large number of mixed ownership enterprises will inevitably require the corresponding innovation and perfection of corporate governance mechanism. Focusing on the core task of corporate governance, some experts and scholars have also carried out research on corporate governance of mixed ownership enterprises[4].

\section{MISUNDERSTANDING OF MIXED OWNERSHIP}

In general, a mixed ownership enterprise refers to an enterprise that includes both state-owned and non-state-owned shares. "Mixed" in mixed ownership enterprises is a mixture of multiple ownership and multiple economic entities, it is a form of realization of the ownership system in China, it is also a new model to deal with the relationship between state-owned enterprises and private enterprises[5]. However, it must be soberly aware that mixed ownership reform is not a "mixing of spirits", as Li mentioned in his article, Road and the Mixed Ownership economy in China, in 2014, to establish mixed ownership enterprises is by no means a simple issue of multiple investment. The key to make a state-owned enterprise to a veritable mixed ownership enterprise is to establish a perfect corporate governance structure and to form a modern enterprise system. Diversification of investment entities is only the first step which much be taken out. However, this is not the same 
thing as establishing and improving corporate governance structures[6]. Therefore, if we want to give full play to the advantages of mixed ownership, which is the organizational form of enterprises, and turn this advantage into the improvement of enterprise performance, we must rely on the reform of corporate governance[7].

Secondly, another misunderstanding of the development of mixed ownership in state-owned enterprises is that the reduction of state-owned capital weakens the strength of stateowned enterprises, and there is a possibility of zero-sum game between state-owned capital and private capital[8]. The development of mixed ownership may, on the surface, reduce the total economic output of state-owned capital. However, it should focus on the control of state-owned capital, rather than merely focusing on the stock of state-owned capital though the stock may decrease[9]. However, as long as the controlling power of state-owned capital still exits, the strength of stateowned enterprises and even the dominant position of the stateowned economy will not change. It is precisely due to the existence of this kind of misunderstanding that the state-owned capital is worried about the loss of control rights and stateowned assets in the early stages of the development of a mixed ownership economy. Private enterprises are concerned about the protection of operating rights and private property rights, and the development of mixed ownership enterprises is hindered. But in essence, the development of mixed ownership is conductive to enhancing the vitality, control and influence of the state-owned economy.

Finally, some views suggest that after the implementation of mixed ownership, enterprises can form a modern corporate governance structure and have a good corporate governance system. Then the main functions of the SASAC evolve into capital investment of capital operation companies. As for the concrete enterprise management does not need to pay attention to. This is a very wrong view, which limits the function of the state-owned investors to the macro level while neglecting the microcosmic operation responsibility of the investors, which is very harmful to the further development of the state-owned economy[10]. It is difficult to separate capital from enterprises. Therefore, at this stage, the SASAC is not a matter of managing capital or of enterprises, but of how to manage it. How can the government select talent into management based on the proportion of state-owned capital equity under the form of a mixed ownership property right organization, is the first consideration of the current problem.

\section{PARTICULARITY OF CORPORATE GOVERNANCE OF MIXED OWNERSHIP ENTERPRISES}

The traditional view is that corporate governance is a whole set of laws, cultures, and institutional arrangements based on incomplete information, contract incompleteness, asset specificity, and power control that are based on the various behaviors of various types of actors within the company[11]. The mixed ownership enterprise has a unique operating mechanism that is different from the state-owned enterprise and the private enterprise. It is different from the traditional state-owned enterprise and the pure private enterprise. Therefore, the research on the corporate governance of mixed ownership enterprise in China must be integrated with our country's own circumstances, and the analysis framework of corporate governance of mixed ownership enterprises must be constructed according to its operating mechanism[12]. The representation of corporate governance is the responsibility and right arrangement between the owner and the board of directors and the management. But behind it is the game between all the participants and the power organization and benefit arrangement formed by the game. This right structure and benefit arrangement are relatively stable in a certain period of time[13]. However, we have also found that corporate governance arrangements cannot be without the influence of social politics. The study of corporate governance, especially the corporate governance of mixed ownership enterprises in China can never ignore the relationship between the government and enterprises. The mixed ownership enterprises must be analyzed under the current situation of reform and macroeconomic system. On the whole, corporate governance of mixed ownership enterprises mainly includes the following aspects:

\section{A. Particularity of Ownership Structure of Mixed Ownership Enterprises}

Ownership structure refers to the composition of the company's shareholders and the proportion of various types of shareholders' shareholdings. Generally speaking, the control right of the company is determined on the basis of the ownership of the company[14]. Therefore, studying the ownership structure of a mixed ownership enterprise is the basis for understanding the particularity of is corporate governance. The third plenary session of 18th CPC Central Committee stressed the need to actively develop a mixed ownership economy with cross-shareholding of state-owned capital, collective capital, and non-public capital. And it allowed more state-owned economy and other ownership economy to develop into mixed ownership economy[15]. On this point of view, it can be seen that the ownership structure of mixed ownership enterprises must be diversified, and its governance structure, state-owned and private enterprises must also have large differences.

According to the proportion of state-owned shares in mixed ownership enterprises, the mixed ownership enterprises can be divided into three types: state-owned absolute holdings, stateowned relative holdings, and state-owned shares. In view of the state-owned holding enterprises, it is believed that the corporate governance should focus on protecting the interests of the minority shareholders, especially the newly entered private enterprise shareholders[16]. Because of the status of state-owned assets is absolutely controlled, it has absolute right to speak in the company's capital operation, investment decision-making, personnel arrangement and so on, while the newly entered non-state-owned shareholders are in a disadvantaged position and lack the corresponding right to speak. If its immediate interests can no longer be guaranteed, it will inevitably lead to difficulties in the establishment of a mixed ownership enterprises, and the company will continue to mix for purely hybrid purposes. In state-owned relative holding companies, the rights of state-owned shareholders and nonstate-owned shareholders are similar, so they can mobilize the enthusiasm of non-state-owned shareholders to participate in 
corporate governance and play a natural advantage in mixedownership enterprises[17]. However, due to the similar ownership arrangements between them, it will be difficult to reach a consensus so that to miss the investment opportunities. Therefore, the focus of corporate governance of this kind of mixed ownership enterprises is to shifted to the question of how to supervise and utilize the non-state-owned capital to state-owned capital. The supervision of non-state-owned shareholders should be aimed at preventing other large and medium-sized from infringing state-owned interests and the possible of losing assets, so as to ensure that non-state-owned shareholders can carry out activities in accordance with market rules and realize the value-added and preservation of stateowned assets.

\section{B. Incentive Issues for Senior Executives in Mixed Ownership Enterprises}

The original intention of mixed-ownership enterprises is to maximize the natural advantages of them, and inject new vitality and motivation for the reform of China's state-owned enterprises so as to realize the preservation of state-owned assets[18]. While corporate executives may not be in line with the interests of enterprises. Many cases have shown at stateowned enterprises, the existing executive incentive system cannot meet the incentive needs of executives, the emerging cases of executive corruption is just an example. Once the contributions and value of enterpreneurs cannot meet their payment, they will seek benefits through on-job consumption or grey transaction.

As a mixed ownership enterprise, it is highly likely that the person in charge or senior management is recommended by the national government department. The identity of these people is "duality", which means the person is in charge of the enterprise and can also be with high administrative level[19]. Here are tricky questions. How should their pay be determined? Is it determined by superior administrative department or based on its market performance? Those non-state-owned shareholder executives have determined the corresponding salary grade or incentive plan according to market performance. A special issue in corporate governance of all mixed ownership enterprises is how to scientifically and effectively determine the compensation incentives for each executive[20].

\section{Relationship between Mixed Ownership Enterprises and Government}

The reason why state-owned enterprises can obtain better operating results, excludes their business management, is in a relatively long period of time, they have a good cooperation with government. They have advantages over non-state-owned enterprises in resources, finance and investment[21]. What kind of relationship should be maintained between mixed ownership enterprises and government after state-owned enterprises carry on mixed ownership reform is the question to be considered while carrying on the corporate governance construction. Is it necessary for government to interpose in enterprises? Should the company run the government alone or maintain a good cooperation with government in order to seek possible benefits? In the meanwhile, it can be found through previous investigations, some enterprises may have some formal or informal contracts with government in the process of carrying out mixed ownership reform. These contracts may make arrangements for the future personnel[22]. It is not allowed by modern enterprise system, but it is necessary to speed up the reform of the mixed ownership, and there is a natural irreconcilable contradiction between the two. How to deal with the relationship between the two is what must be considered in construction of mixed ownership corporate governance framework[23].

\section{COUNTERMEASURES TO IMPROVE CORPORATE GOVERNANCE OF MIXED OWNERSHIP ENTERPRISES}

By analyzing the particularity of mixed ownership corporate governance, we should start from the following aspects to improve the corporate governance of mixed ownership enterprises gradually.

Firstly, the positive effect of corporate governance of large shareholders should be further strengthened. Whether it is a state-owned or not, if they can implement reasonable incentives, it can achieve its positive impact on corporate governance. What is important is how to achieve it and how to restrict the majors' self-interests tendencies. Therefore, in the formulation of corporate governance regulations, it should be clear that the major shareholders should bear the responsibilities and obligations. It should ensure the interests of the majority shareholders and support the strategic decisions and functions of them through clear material or non-material incentives. At the same time, it should give full play to the supervision function of the minority shareholders to ensure that the major shareholders can develop according to the established operation.

Secondly, we should improve regulatory environment and regulate the operation of the board of directors. The nature of mixed ownership enterprises has been clarified in the existing documents, which provides the basic guarantee for the development of mixed ownership economy, but some detailed contents still need to be safeguarded by more perfect laws and regulations. For example, the interests of minority shareholders in mixed ownership enterprises, information disclosure, shareholder incentives and so on are worthy of attention. In mixed ownership enterprises, due to the diversity of sources of shareholders, it will inevitably take more time to coordinate interests and arrange power between the parties. If the arrangement is not proper, it may not affect the development and operation of the enterprise. This requires a complete set of institutional arrangements within the enterprise to coordinate and formulate the rights and obligations of all parities (the board of directors system). The effect of the board of directors system doesn't work well though it has been implemented for a long time in China. In mixed ownership enterprises, the duties, rights and obligations of board members should be clearly elaborated and refined in articles of association in order to avoid unclear powers and responsibilities.

Finally, the relationship between mixed ownership enterprises and government should be taken care of. Whether it is a state-owned enterprise or not, the purpose of its operation is to obtain greater benefits. When government can bring considerable economic benefits to non-state-owned enterprises, 
though they are more willing to run companies according to modern enterprise system, the shareholders are willing to establish a good relationship with government. Therefore, when faced with the existence special agreement clauses in mixed ownership enterprises, they can guarantee and deal with exiting contracts from the institutional level, which can not only meet the agreement of some special clauses, but not violate the requirements of modern enterprise system.

\section{CONCLUSION}

The development of mixed ownership economies is an important form in China. It is also the basic direction and core task of deepening the reform of state-owned enterprises. They can not only play the characteristics of flexible and efficient non-public ownership, but enjoy the resources, opportunities and other conveniences brought by public ownership, and take the corresponding social responsibilities. At this stage, deepening the reform of the state0owned enterprises is still the core task to the reform of economic system in China. It is of great theoretical and practical value to accelerate the reform of state-owned enterprises and the development of mixed ownership economy in China.

\section{REFERENCES}

[1] M. Backx, M. Carney, and E. Gedajlovic, "Public, private and mixed ownership and the performance of international airlines," Journal of Air Transport Management, vol. 8, pp. 213-220, 2002.

[2] G. Li and S. Sun, "Study on the Problems of Management Shareholding and the Mixed Ownership," International Journal of Economics, Finance and Management Sciences, vol. 5, pp. 304-315, 2017.

[3] G. Grossi, U. Papenfuß, and M.S. Tremblay, "Corporate governance and accountability of state-owned enterprises: relevance for science and society and interdisciplinary research perspectives," International Journal of Public Sector Management, vol. 28, pp. 274-285, 2015.

[4] H. Berkman, A. Cole, and J. Lawrence, "Improving corporate governance where the State is the controlling block holder: evidence from China, " The European Journal of Finance, vol. 20, pp. 752-777, 2014.

[5] L.A. Bebchuk and S.W. Michael, "The state of corporate governance research," The Review of Financial Studies, vol. 23, pp. 939-961, 2010.

[6] M. Pargendler, "State ownership and corporate governance," Fordham L. Rev., vol. 80, pp.2917, 2011.
[7] B.L. Connelly, R.E. Hoskisson, and L. Tihanyi L, "Ownership as a form of corporate governance," Journal of management studies, vol. 47, pp. 1561-1589, 2010.

[8] H. Darren, "Agency costs, ownership structure and corporate governance compliance: A private contracting perspective, " PacificBasin Finance Journal, vol. 18, pp. 24-46, 2010.

[9] T. Li, "State Ownership of Mixed Ownership Firms: Theoretical Foundation of Reducing Government Shareholding Fraction," Economic Research Journal, vol. 8, pp. 19-27, 2002.

[10] X. Xu and Y. Wang, "Ownership structure and corporate governance in Chinese stock companies, " China economic review, vol. 10, pp. 75-98, 1999.

[11] X. Lin and Y. Zhang, "Bank ownership reform and bank performance in China," Journal of Banking \& Finance, vol. 33, pp. 20-29, 2009.

[12] F. Robins, "China: a new kind of 'mixed'economy?" Asian Business \& Management, vol. 9, pp. 23-46, 2010.

[13] J. Chen, "Development of Chinese small and medium-sized enterprises, " Journal of Small Business and Enterprise Development, vol. 13, pp. 140-147, 2006.

[14] Y. Huang, Y. Sun, and Y. Shao, "Equity-structure-approach to Solve Corporate Governance Problem," JOURNAL-TONGJI UNIVERSITY, vol. 31, pp. 1102-1105, 2003.

[15] K.V. Lins, "Equity ownership and firm value in emerging markets, " Journal of financial and quantitative analysis, vol. 38, pp. 159-184, 2003

[16] Z. Yu, "China's State-owned Enterprise Mixed Ownership Reform," East Asian Policy, vol. 6, pp. 39-50, 2014

[17] Y, Hao and Q. Wang, "Research on the equity check and balance mechanism of the mixed ownership enterprises-Based on the case analysis of" the dispute over control rights of 'E Wushang, "'”' China Industrial Economy, vol. 3, pp. 148-160, 2015.

[18] S. Huang, "Study on the Mixed Ownership Reform of China's SOEs," Journal of Economic Management, vol. 7, pp. 1-10, 2014.

[19] C. Lin and Y. Tang, "The mixed ownership reform and the policy burden of state-owned enterprises-An empirical study based on big data of property rights reform of early state-owned enterprises," Economist, vol. 11, pp. 13-23, 2014

[20] M. Yu, "State ownership and firm performance: Empirical evidence from Chinese listed companies, " China Journal of Accounting Research, vol. 6, pp. 75-87, 2013.

[21] T. Michaela, "State or private ownership? A survey of empirical studies, "Review of Economic Perspectives, vol. 12, pp. 120-144, 2012

[22] Z. Zhao, B. Li, and S. Qin, "Does the Mixed Ownership Trap Really Exist?-Micro Evidence of Transownership Mergers and Acquisitions of Privately Operated Companies in China, " Finance \& Economics, vol. 6, pp. 9-14, 2017.

[23] S.P. Katz, "Earnings quality and ownership structure: The role of private equity sponsors," The Accounting Review, vol. 84, pp. 623-658, 2009. 